\title{
Evaluating Adoption of Information Communication Technology in Agricultural Green Production to Increase Net Returns
}

\author{
Jie Sheng, Arshad Ahmad Khan, Shaofeng Zheng, Qian Lu* \\ College of Economics and Management, Northwest A\&F University, Yangling, 712100, Shaanxi, China
}

Received: 14 December 2020

Accepted: 17 March 2021

\begin{abstract}
At present, the use of chemical fertilizers and pesticides in China is significantly higher than the world's average level, and it has caused many environmental problems. How to promote the reduction of chemical fertilizers and pesticides while increasing the income of farmers has always been the focus of government and scholars. A full understanding of the reasons leading to this phenomenon is of great significance to better respond to and promote the green and sustainable development of modern agriculture in China. Based on theoretical analysis and survey data of 1989 farmers in typical vegetable growing areas of Shandong, Hebei and Shaanxi provinces, this study examined the impact of farmers use of information communication technology on their net income and its mechanism. The study found that keeping other conditions unchanged, the farmers in the benchmark regression results have a significant and positive relationship in the degree of farmers using information communication technology in production, sales and the net income. After the use of instrumental variables to control the endogenous problem, for every standard deviation that farmers use information communication technology in production and sales doubles, the net income of farmers may increase by 0.517 times the standard deviation. Using the Karlson, Holm and Breen method to analyze the mechanism, the results showed that the use of information communication technology by farmers would lead to technological progress and supply decision adjustments by choosing green production behaviors, thereby increasing net income. Further decomposition finds that these indirect effects can explain $13.8 \%$ of the increase in net income of farmers using information communication technology and the contribution rates are $56.30 \%$ and $15.42 \%$ respectively. This paper verifies the green income-increasing effect of the application of information technology at the farm level and has strong policy implications for how to guide farmers through scientific fertilization and information to reduce the use of chemical fertilizers
\end{abstract}

*e-mail: xnluqian@126.com 
and to solve the problem of non-point source pollution caused by excessive fertilizer application and to promote sustainable agricultural development.

Keywords: information communication technology, environmental pollution, green production behavior, net income, Holm and Breen method

\section{Introduction}

Fertilizers and pesticides are two important production materials in the modern agricultural production process. As one of the signs of the "Green Revolution", fertilizers and pesticides are widely used in modern agricultural production. However, farmers have not considered the social costs caused by environmental quality loss, the goal orientation of profit maximization will inevitably lead to excessive application of chemical fertilizers with negative environmental effects [1, 2]. The Green Revolution is an agricultural production technology reform activity carried out by developed countries in third world countries. In order to distinguish it from the "industrial revolution" of the 18th century, it is called the "green revolution". The main content of this activity is to cultivate and promote high-yield grain varieties, increase the amount of fertilizers, strengthen irrigation and management, use pesticides and agricultural machinery to increase the yield per unit area and increase the total grain output. The negative environmental effects caused by the excessive use of irrigation water, chemical fertilizers, and herbicides brought about by the first green revolution should be taken as a warning. Based on this background, the article emphasizes the implementation of environmentally friendly green technologies and reduces the intensity of fertilizer and pesticide use to promote green and sustainable agricultural development.

In 2016, the intensity of chemical fertilizer used per sown area in China reached $359.08 \mathrm{Kg} / \mathrm{hm}^{21}$ (of which nitrogen fertilizer accounts for about $55 \%$ ), which is far higher than the safety upper limit of $225 \mathrm{Kg} / \mathrm{hm}^{2}$ set by developed countries [3]. Long-term excessive use of chemical fertilizers can easily cause soil compactness, acidification and nutrient structure imbalance, which will reduce soil fertility and ultimately lead to a decline in crop yield and quality. The production of chemical fertilizers relies on mineral resources such as coal, oil and apatite, thus causing the consumption of mineral resources and environmental pollution along with rise in raw material prices. Excessive fertilizer use has increased the cost of agricultural activities (production), which has also contributed to the decline in the growth rate of farmers' income in recent years [4]. Similarly, excessive use of chemical fertilizers also causes serious agricultural non-point source pollution. Taking nitrogen and phosphate fertilizers as an example, the annual

\footnotetext{
$\mathrm{Kg} / \mathrm{hm}^{2}=$ Kilogram per square hectometer. 1 hectometer $=100$ meter
}

loss of nitrogen fertilizer applied to the land in China is $124.8 \mathrm{Kg} / \mathrm{hm}^{2}$, and the loss of phosphate fertilizer is $38.8 \mathrm{Kg} / \mathrm{hm}^{2}$ [5]. Moreover, the high application of nitrogen and phosphorus nutrients enter rivers, lakes and groundwater through surface runoff and infiltration, causing serious water eutrophication, groundwater nitrate and nitrite pollution, etc., and can endanger human health through certain exposure pathways [6]. Pesticides are a major "three-causing" substance, and their carcinogenic and mutagenic incubation period can be as long as decades. After pesticides are used in the field, only $10-30 \%$ of the pesticides can be used effectively. The remaining $20 \%-30 \%$ enter the atmosphere and water bodies through diffusion and runoff, while $50-60 \%$ remain in the soil [3]. The wide range application of pesticides poses a severe threat to farmers' health, crop safety, agricultural product quality and safety as well as the ecological environment [7]. Therefore, in response to the pollution due to pesticides and fertilizers, in 2015 the Ministry of Agriculture of China proposed the "Zero Growth Action for the Use of Pesticides and Fertilizers by 2020", requiring that the utilization rate of pesticides and fertilizers should be increased and the amount of pesticides and fertilizers used should be reduced. The 2018 National Rural Revitalization Strategic Plan (2018-2022) clearly put forward the requirement of "promoting the reduction of pesticide and fertilizer use" in the measures of "promoting cleaner agricultural production". In the critical period of "adjusting structure and changing mode" of China's agricultural development, how to closely focus on changes in market demand, reduce agricultural pollution and circulation losses, and achieve green income growth for farmers and green development of agriculture to become China's "three rural" (farmers, rural areas, and agriculture) important issues facing the business [8].

As the main body of farmers using chemical fertilizers and pesticides, the micro decision-making mechanism of their chemical fertilizer and pesticide use behavior has always been the focus of discussion among scholars $[9,10]$. Among them, the dissemination of agricultural information plays an important role in the agricultural production, management and decision-making process of farmers. Farmers have insufficient awareness of environmental pollution, insufficient government guidance and input, insufficient information collection and dissemination methods, and often mismatches between the information requested by farmers and the information released through public channels, and other factors have led to poor dissemination of agricultural information [11]. 
Information asymmetry in the agricultural product market and environmental awareness [12] leads to higher information search costs, which affects the sales behavior of economic agents and may lead to inefficient market results $[13,14]$. Studies have shown that, information communication technology is an effective tool for overcoming farmers' "information barriers" [15]. Whereas, it reduces the cost of finding agricultural information, speeds up the flow of information and widens the channels of information exchange, thereby alleviating market information asymmetry and unevenness and completeness $[16,17]$. The propagation and application of information communication technology has greatly reduced and eliminated barriers to market information in terms of time and space, and improved the access to information and services [18]. On the other hand, the new economic growth theory proposes that technological progress is the main driving force for economic growth, and the development of information communication technology has promoted the progress of agricultural information and has become one of the important driving factor for the progress of agricultural green technology [19]. Therefore, since 2017, the No. 1 document of the Central Committee of China and the report of the 19th National Congress of the Communist Party of China have proposed that "vigorously promote modern agricultural information, apply information technologies such as mobile internet, promote the transformation and upgradation of the entire agricultural industry chain and expand the space for farmers to increase income". At the same time, the "Thirteenth Five-Year" National Agricultural and Rural Information Development Plan, "Agricultural and Rural Information Development Prospects and Policy Guidance", the Digital China Construction Summit and the World Internet Conference and other policy programs and conferences were closely introduced and carried out, and coordinated arrangements. Work on agricultural and rural information, advancing the construction of agricultural information, and strengthening the integration of modern agriculture and information technology [20], so that the farmers can shift from relying on labor and resource input to rely on technological advancement as well as providing them new ideas and guidelines for tackling environmental pollution and increasing income.

So far, there is no consensus in the theoretical community that the use of information communication technology can affect income and can increase it. Some scholars believe that information communication technology has a positive and significant impact on the farmers' income by reducing the cost of information search. Svensson and Yanagizawa [21], through the study of Ugandan farmers' data, pointed out that access to market information services through communication technology has a significant and positive impact on the farmers' agricultural product prices and income. Based on survey data of fishermen in developing countries, Jensen [22] found that the use of mobile phones can help
Indian fishermen to understand the market information and choose high-value markets, expanding market sales, helps in reduction of resource wastage, and increase fishermen's income. Information communication technology can improve agricultural productivity of rural households and increase agricultural income in rural areas of developing countries [23]. Other scholars believe that information communication technologies have certain preconditions for income growth, such as, their income growth is only for high income farmers [24] and having a significant and positive impact on the farmers who are producing high-value perishable agricultural products [25]. Some scholars also believe that information communication technology has little effect on farmers' income, such as, Camacho and Conover [26] based on Colombian farmers' survey data while Mitra, Mookherjee [27] based on Indian farmers' survey data concluded that information technology has no effect on farmers' income. Similarly, the research of Fafchamps and Minten [28] also showed that, overall, information communication technology has no effect on farmers' income growth, and only slightly positive impact on young farmers' income.

Existing literature conducts empirical research on the relationship between the use of information communication technology and farmers' income, and draws inconsistent or even opposite conclusions. This difference may be caused by: first, the current research about the impact of information and communication technology on agricultural income or farmers' behaviors, the selected information and communication technology characterization variables mostly use whether to have information and communication technology or whether to use information and communication technology, and simply owning or using technology does not objectively reflect whether farmers use information tools in agricultural production. Therefore, the article selects whether farmers use information communication tools in agricultural production to more objectively and accurately characterize the main influencing variables [29].

The second is the lack of in-depth analysis and testing of the mechanism of information communication technology impact on increasing revenue. The existing literature has not yet examined the impact of changes in market behavior of farmers on their income through information communication technology and the extent of this impact at the farmer level. Taking into account that Chinese vegetables are the most widely cultivated and economically important crops except food crops, the vegetable industry has become a major pillar industry in the vast rural areas, and the use of chemical fertilizers and pesticides in the vegetable industry is generally high. Based on this, the current study uses the micro-level survey data of typical vegetable production and pesticide and fertilizer use areas in China in order to investigate whether farmers are increasing their use of information communication technology and whether it enhanced the farmers' income and further 


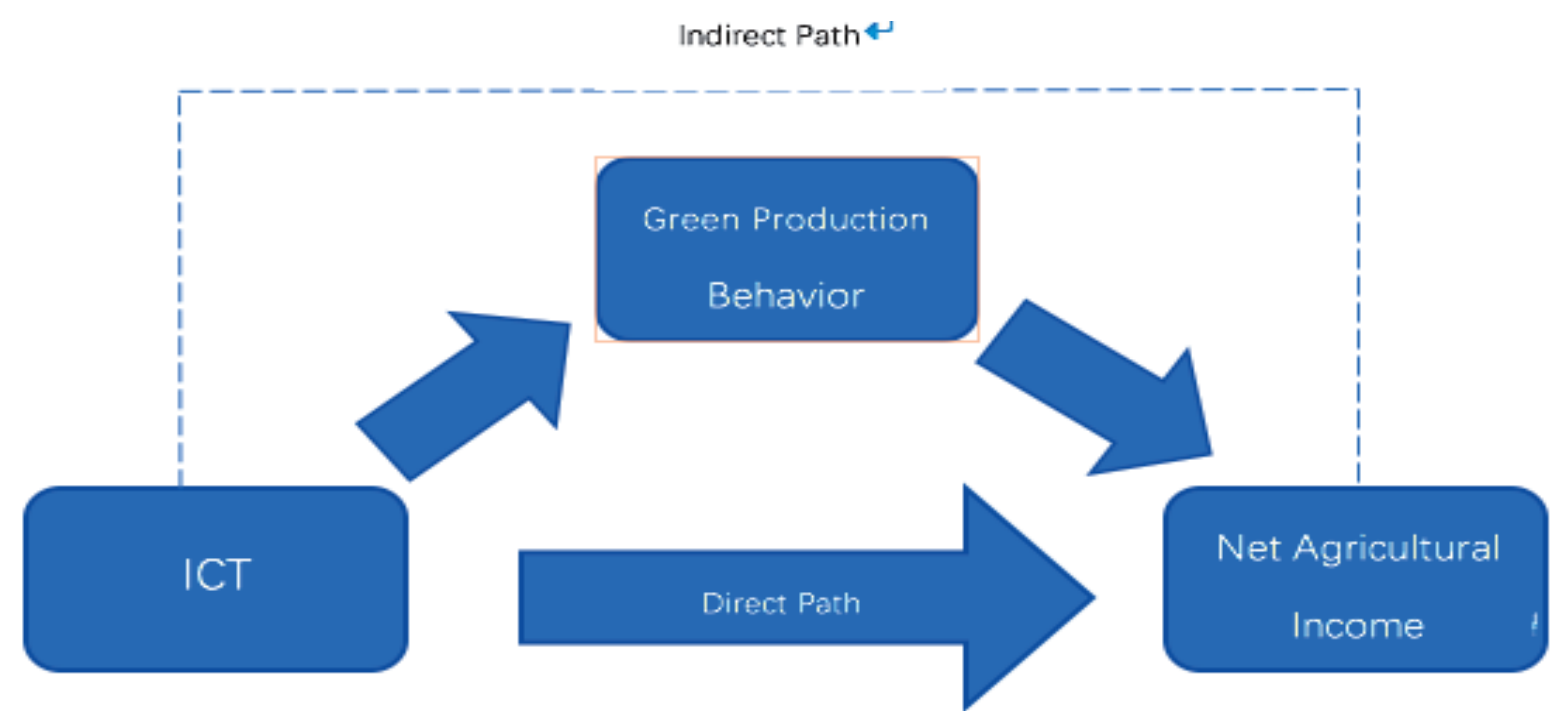

Fig. 1. Logical framework. Note: ICT denotes information communication technology.

analyzes whether the use of information communication technology by farmers has increased farmers' green production. As well as how much increase in the environmental benefits of farmers has brought by this behavior.

Located in the hinterland of the Guanzhong Plain, Xixian City in Shaanxi Province has a warm temperate monsoon climate, a mild climate, abundant light, heat, and water resources, which is conducive to the development of vegetable planting. Among them, the vegetable area in Xi'an in 2017 was 88,200 hectares and the output reached 445.43 million tons. The planting area of vegetables in Xianyang City in 2017 was 84,900 hectares, and the output reached 3.6186 million tons. Shouguang, Shandong Province is located on the coast of northern Shandong, on the south bank of Laizhou Bay in the Bohai Sea and northwest of Weifang City. It is the "Hometown of Vegetables in China". In 2016, the sown area of vegetables was 54,700 hectares, and the output was 4.566 million tons, ranking first in the province. Langfang City is located between the two major cities of Beijing and Tianjin. It is an important part of the green economic circle around the capital. The development of vegetable industry has unique advantages. In 2017, the sown area of vegetables in Langfang City was 102,200 hectares, with a total output of 6.389 million tons. ${ }^{2}$ After years of development, the vegetable industry has become a pillar industry for increasing agricultural efficiency and increasing farmers' income in Xixian, Shouguang and Langfang, and has become a major area for vegetable production in China.

\footnotetext{
Sources of data: 2017 Shaanxi Provincial Statistical Yearbook, 2017 Shandong Provincial Statistical Yearbook and 2017 Hebei Provincial Statistical Bulletin of National Economic and Social Development
}

Compared with the existing literature, the main contributions of this article are as follows: First, selection of farmers and their associated degree of using information communication technology to obtain information as the core independent variable to increase the accuracy of estimating the impact of information communication technology. Second, this article clarifies the indirect green effect of the application of information communication technology on farmers' income, which will be achieved through two specific channels i.e. reduction in the use of fertilizers and pesticides. The Karlson, Holm and Breen model is used to verify and find out the effect of each channel which is expected to reveal in depth the impact of information tools used by farmers' on their green income and the path of influence transformation, and provide theoretical and empirical support for the exploration of increasing farmers' income. (The logical framework of the article is as follows).

\section{Materials and Methods}

\section{Farm Survey and Study Area Description}

The research data comes from the 'Research on the Impact Mechanism of the Use of information communication technology on farmers' market participation behavior and performance - based on the perspective of transaction Costs and household survey of vegetable growers. The relevant data was collected from vegetables growing areas of Xian and Xianyang in Shaanxi Province, Shouguang in Shandong Province, and Langfang in Hebei Province (see Fig. 2). The vegetable industry has become a major industry in the Xixian, Shouguang and Langfang to increase agricultural efficiency and farmers' income. In addition to the systematic training of the pre-survey recruited investigators, a pilot survey was conducted in order to 


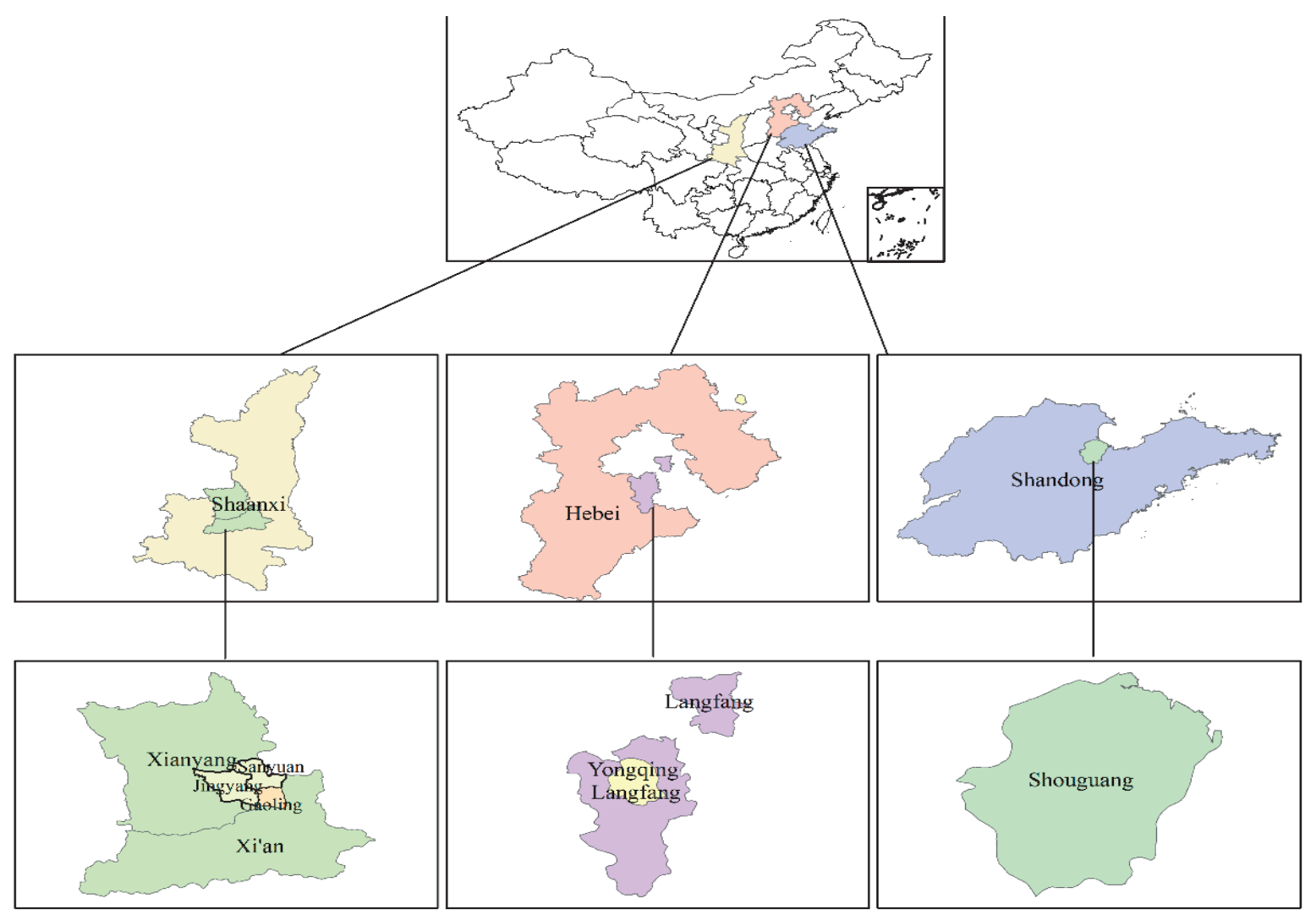

Fig. 2. Study areas in different eco-environmental zones (Arc GIS 10.3).

reduce misunderstandings about pre-survey vegetable growers' questionnaire and to improve the authenticity and validity of field survey data. Based on the pilot survey, the questionnaire was revised and improved (attached as supplementary file). The final field survey used a combination of typical sampling, stratified random sampling and simple random sampling. First, the typical survey method was used to select four main vegetable growing areas in Xi'an, Xianyang, Shouguang and Langfang. Secondly, a combination of stratified sampling and simple random sampling was used to select 2-3 counties in the above 4 cities and 10-12 villages were selected in each county, and finally 10-15 farmers were randomly selected in each village through face-to-face interview. A total of 1989 valid questionnaires were obtained, including 589 from Shaanxi Province, 798 from Shandong Province and 602 from Hebei Province. The contents of the questionnaire included household heads and their family socioeconomic characteristics, planting conditions,

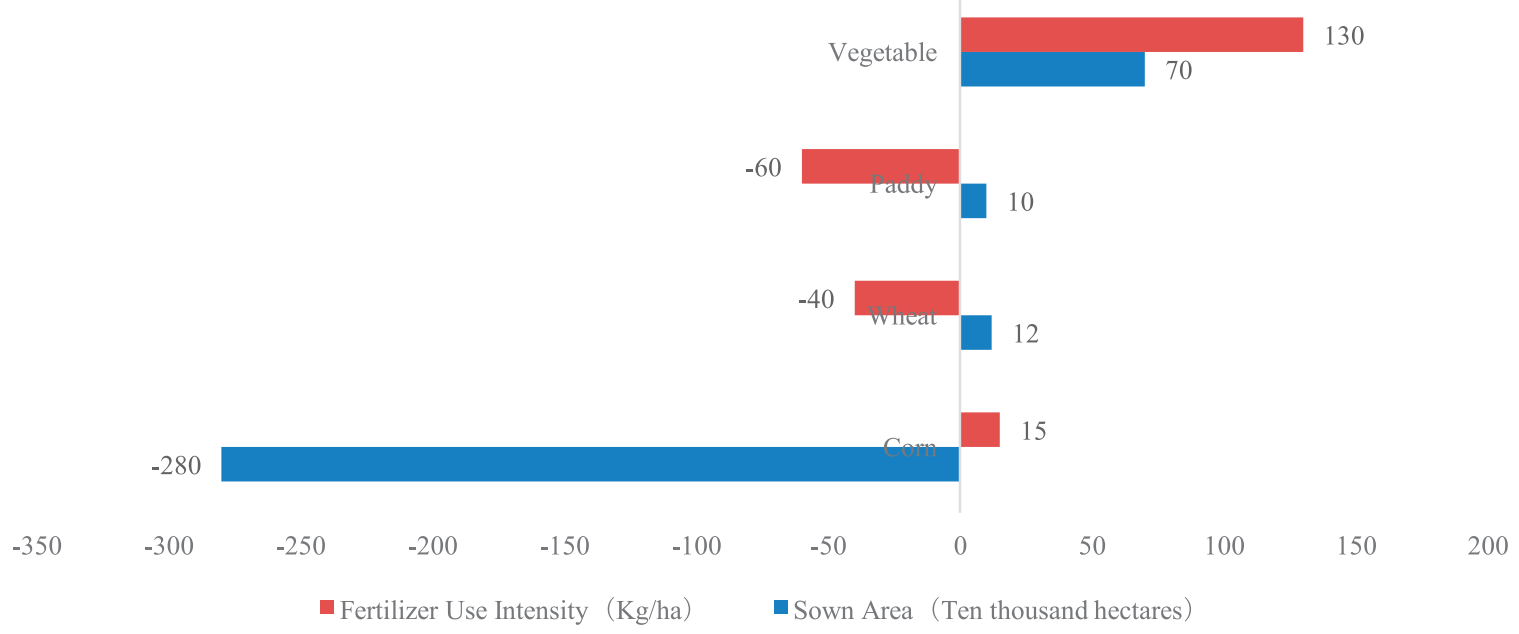

Fig. 3. Sown area of different plants and intensity of fertilizer application. 
information acquisition, regional environment and farmers' market participation behaviors.

Since 1980s, vegetable planting has been a new agricultural industry in China, and farmers have not learned reasonable fertilization techniques. Due to the high efficiency of vegetable planting, vegetable farmers in pursuit of efficiency, used extremely high amounts of nitrogen and phosphorus fertilizers and pesticides. The average amount of pure nutrients for single-season crops is $569-2000 \mathrm{Kg} / \mathrm{ha}$, which is several times or even dozens of times that of ordinary traditional crops. It has become one of the main potential threats to agricultural environmental pollution (Report on the State of the Environment in China in 2018). In the year 2018, the total use of chemical fertilizers for vegetables in China increased by 2,806,700 Tons compared to 2015, and the average use of chemical fertilizers and pesticides per hectare for vegetables was much higher than that of food crops (see Fig. 3). As a typical vegetable growing area in China, the surveyed area has serious environmental problems caused by fertilizer and pesticide pollution [30]. Among them, Shaanxi Province is an area with extremely heavy non-point source pollution of chemical fertilizers $\left(>500 \mathrm{Kg} / \mathrm{hm}^{2}\right)$, Shandong Province is an area with heavy non-point source pollution of chemical fertilizers $\left(400 \mathrm{Kg} / \mathrm{hm}^{2}<\mathrm{a} \leq 500 \mathrm{Kg} / \mathrm{hm}^{2}\right)$, and Hebei Province is an area with moderate non-point source pollution of chemical fertilizers $\left(300 \mathrm{Kg} / \mathrm{hm}^{2} \leq \mathrm{a} \leq\right.$ $400 \mathrm{Kg} / \mathrm{hm}^{2}$ ). In 2018, the intensity of fertilizer and pesticide use in the three provinces was much higher than the national level (see Fig. 4). As the main vegetable growing area in China, the excessive use of chemical fertilizers and pesticides has brought many environmental problems to these three provinces. There is a certain degree of water pollution in the Weihe River Basin of Shaanxi Province, the basin of Shandong Province, and the Yongding River Basin of Hebei Province, as well as groundwater is also affected. In addition, pesticide residues will also have an impact on the sales of vegetables, and ultimately affect the income of farmers [31].

\section{Variable Specifications}

\section{Net Income}

In the questionnaire, farmers were asked to determine the total income and total expenditure of each surveyed household from planting vegetables in 2016, the net income value of each household's vegetables was obtained according to the formula Net income $=$ Total income - Total expenditure. In order to make the data more accurate, consider the major differences in the area of vegetable planting owned by the surveyed households, the final dependent variable is net income $=$ net vegetable planting income/total vegetable planting area.

\section{Narrative for Use of Information Communication Technology}

Existing studies mostly stated that whether farmers have information communication technology or the costs incurred in their use as variable indicators, but the fact is that farmers own high technology does not mean that they have a large role in farmers' agricultural production [29]. In the survey, the proportion of sampled households owning mobile phones and computers is relatively high, reaching $97.74 \%$ and $59.99 \%$ respectively, but in the case of high ownership, the proportion of farmers actively using information communication technology to help their agricultural production is relatively low, accounting for only $34.24 \%$ [32]. Therefore, what we need to pay attention is whether the farmers with information communication technology use technology to produce an impact. The use of information communication technology has a significant impact on farmers' technology adoption and market participation [33, 34]. Combining with the availability of data and drawing on the research of Zhang, Zhou [35], this article uses the questionnaire "how much do you use information communication technology in agricultural production and sales" as the core independent variable question. The options

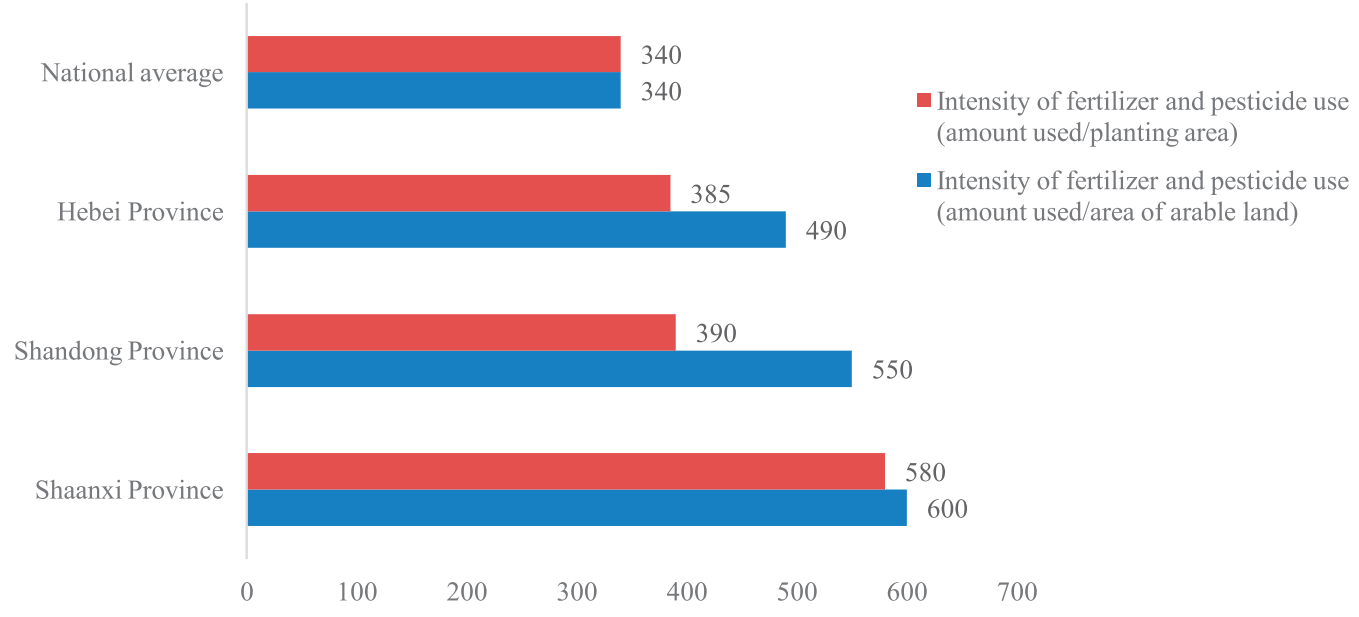

Fig. 4. Intensity of fertilizer and pesticide application in the investigated area (unit: $\mathrm{Kg} / \mathrm{ha}$ ). 
to answer this question are "never use", "rarely used", "sometimes used", "usually used" and "always used". This article assigns these options to $1,2,3,4,5$ in turn, the higher the value means the higher application of information communication technology in the production and sales of farmers.

\section{Green Production Behavior}

Selecting organic fertilizers and reducing the use of pesticides for safe production are the requirements for the development of agricultural modernization [36]. Information communication technology can increase the dissemination of information and deepen the integration of technologies to promote the use of safe production technologies. Two specific variables i.e., "Whether organic fertilizers are the main purchase in agricultural production?" and "Does vegetable production reduce the use of pesticides?" are selected to highlight green production behavior. The use of organic fertilizer instead of chemical fertilizer is of great significance for improving soil fertility, reducing agricultural non-point source pollution and improving the quality of agricultural products. Promoting the reduced use of fertilizers and pesticides by farmers is an important measure to improve agricultural non-point source pollution and to promote sustainable agricultural development.

\section{Control Variables}

In order to avoid other factors that may affect the market selection behavior and interfering with farmers' net income assessments results, this paper selected gender, age, years of education, transaction costs, years of vegetable cultivation, political outlook, whether family members have village leaders, and vegetable population ratio, vegetable planting structure, whether to participate in a cooperative, the distance to the nearest sales market, and whether the government has conducted relevant agricultural promotional training as control variables [37-40]. In addition, this paper also added dummy variables of the province where farmers are located to capture some unobservable regional factors (such as the impact of geographic location or local specific economic policies) for robustness testing (see Table 3 for details).

\section{Research Methods and Model Construction}

\section{Transaction Cost Measurement}

The prevailing information monopoly in the agricultural product market has significantly increased the transaction costs for farmers to enter the market. When farmers switch from grain planting to producing high value-added agricultural products, they face higher entry barriers and circulation constraints. Transaction

Table 1. Variable description statistics.

\begin{tabular}{|c|c|c|c|}
\hline Variable type and name & Description & Mean & SD \\
\hline $\begin{array}{l}\text { Dependent variable: } \\
\text { Net income }\end{array}$ & Net income from sales of vegetables/area in 2016 (ten thousand yuan/mu) & 1.602 & 1.805 \\
\hline $\begin{array}{l}\text { Core independent variable: } \\
\text { ICT }\end{array}$ & $\begin{array}{l}\text { The extent to which farmers use ICTin production and sales: } \\
\text { Never }=1 \text {, rarely }=2 \text {, sometimes }=3 \text {, often }=4 \text {, always }=5\end{array}$ & 2.992 & 1.382 \\
\hline \multirow{2}{*}{$\begin{array}{l}\text { Green production behavior } \\
\qquad(\mathrm{GPB})\end{array}$} & $\begin{array}{l}\text { Whether to purchase organic fertilizer as the main fertilizer in agricultural } \\
\text { production: Yes }=1, \mathrm{No}=0\end{array}$ & 0.816 & 0.387 \\
\hline & Does vegetable production reduce the use of pesticides: $\mathrm{Yes}=1, \mathrm{No}=0$ & 0.896 & 0.305 \\
\hline $\begin{array}{c}\text { Control variable: } \\
\text { Gender } \\
\text { Age } \\
\text { Education Year of growing } \\
\text { Political status } \\
\text { Village cadre } \\
\text { Population ratio } \\
\text { Planting structure } \\
\text { Infrastructure }\end{array}$ & $\begin{array}{c}\text { Gender of household head: male }=1 \text {, female }=0 \\
\text { Age of household head (years) } \\
\text { Years of education of household head (years) } \\
\text { Number of years the head of household has grown vegetables (years) } \\
\text { Whether the head of household is a party member: Yes }=1, \text { No }=0 \\
\text { Is anyone in the family serving as a village cadre: yes }=1 \text {, no }=0 \\
\text { The ratio of the number of laborers who grow vegetables to the total number } \\
\text { of households } \\
\text { Vegetable planting area as a percentage of total planting area } \\
\text { The degree of perfection of the regional market infrastructure: } \\
\text { very imperfect }=1 \text {, relatively imperfect }=2 \text {, general }=3, \\
\text { relatively complete }=4 \text {, very complete }=5 \\
\text { Whether to participate in a cooperative: Yes }=1, \text { No }=0 \\
\text { Distance from planting place to nearest sales market (mile) } \\
\text { Yes }=1, \text { No }=0\end{array}$ & $\begin{array}{c}0.977 \\
51.288 \\
7.370 \\
18.312 \\
0.033 \\
0.045 \\
0.478 \\
0.771 \\
3.120 \\
\\
0.173 \\
5.220 \\
0.027\end{array}$ & $\begin{array}{c}0.149 \\
9.95 \\
2.396 \\
8.758 \\
0.178 \\
0.207 \\
0.179 \\
0.288 \\
1.317 \\
\\
0.378 \\
6.981 \\
0.163\end{array}$ \\
\hline Transaction cost & Factor analysis to calculate score & $-8.589 \mathrm{E}-9$ & 0.517 \\
\hline
\end{tabular}

Note: ICT denotes information communication technology 
costs have become the primary factor hindering farmers from entering a competitive market [1-2]. Information is an important factor affecting transaction costs. Market information can help farmers reduce transaction costs, increase market participation, and improve market performance [3]. Information communication technology by reducing transaction costs and expanding market choices for farmers, increased the welfare of small farmers and has become an effective tool for overcoming farmers' "information barriers" [4]. Therefore, transaction costs play an important role in the process of information and communication technology affecting agricultural production, so this article emphasizes it. In addition, existing studies have different methods for measuring transaction costs, and most of them directly use variables to represent them. The measurement methods of this study are different from previous studies, so the main text is added.

In this paper, by applying the Likert 5-point scale, combined with the actual situation of the transaction costs of farmers in the sales process. SPSS 22.0 software is used to conduct exploratory factor analysis on the variables of farmers' transaction costs (see the attachment for the selection of specific variables) to avoid multicollinearity among variables [32]. First, standardize the transaction cost index data to eliminate the impact caused by the difference in the observational dimension, and then perform the KMO test on the standardized data, with a statistical value of 0.687 . Bartlett's spherical test approximates the chi-square value and the corresponding p-value that are 3055.187 and 0.00 respectively, indicating that the indicators are suitable for factor analysis.

Secondly, in order to give a better reasonable explanatory connotations to the extracted common factors, the maximum variance method is used to rotate the factor loading coefficients, and the cumulative variance contribution rate of the extracted four common factors is $75.613 \%$. The variance contribution rate of common factor 1 is $26.625 \%$, including three variables; price understanding, price accuracy, and information difficulty. These variables are all related to the cost of farmers searching for information before the transaction, so they are defined as the information search cost factor (F1). The variance contribution rate of common factor 2 is $16.181 \%$, including price difference and price fairness variables. These two types of situations are usually generated while negotiation with the buyer during the transaction process, so they are defined as the negotiation cost factor (F2). The variance contribution rate of common factor 3 is $19.477 \%$, which includes two indicators of price fairness and trust level, indicating the cost incurred by farmers in executing transactions, which is defined as the supervision execution cost factor (F3). The variance contribution rate of the common factor 4 is $13.331 \%$, which only includes the transportation difficulty variable that reflects the cost incurred in the transportation process, which is defined as the transportation cost factor (F4).
Finally, according to the variance contribution rate, the weighted sum of the scores of each factor is performed, and the individual transaction cost index of each farmer can be obtained.

$$
\begin{gathered}
\text { Transaction cost }=(26.625 \times \mathrm{F} 1+16.181 \times \\
\mathrm{F} 2+19.477 \times \mathrm{F} 3+13.331 \times \mathrm{F} 4) / 75.613
\end{gathered}
$$

\section{Karlson, Holm and Breen Model}

The Karlson, Holm and Breen model was created and developed by Karlson, Holm and Breen [41]. This model is used to verify the mediating effect of information communication technology use that affects the net income of farmers in agriculture and to measure the total effect, direct effect and indirect effect.

Assuming a linear regression model:

$$
\mathrm{Y}=\alpha_{F}+\beta_{F} \mathrm{X}+\gamma_{F} \mathrm{Z}+\delta_{F} \mathrm{C}+\epsilon
$$

Among them, $\mathrm{X}$ is the core explanatory variable to be decomposed; $\mathrm{Z}$ is the vector of intermediate variables, and $X$ can indirectly act on the dependent variable $\mathrm{Y}$ through the influence of $\mathrm{Z}$. Under this assumption, it is the direct effect of variable $\mathrm{X}$ on $\mathrm{Y}$, and the total effect of $\mathrm{X}$ on $\mathrm{Y}$ can be obtained by the following simplified model (Reduced Model):

$$
\mathrm{Y}=\alpha_{R}+\beta_{R} \mathrm{X}+\delta_{R} \mathrm{C}+\varepsilon
$$

Then, the indirect influence of $\mathrm{X}$ through the influence of $\mathrm{Z}$ on $\mathrm{Y}$ is:

$$
\beta_{\mathrm{I}}=\beta_{R}-\beta_{F}
$$

\section{Test of Indirect Effects of Karlson Holm and Breen Model}

In order to verify the intermediary effect in the above model, only the hypothesis $\mathrm{H}_{0}: \beta_{R}=\beta_{F}$ is needed to be tested: that is, to test whether and is equal to each other. Using Sobel's delta theory, the following test for indirect effects can be obtained:

$$
\mathrm{Z}=\frac{\sqrt{N}\left(\beta_{R}-\beta_{F}\right)}{\sqrt{\alpha^{\prime} \sum \alpha}} \sim N(0.1)
$$

Among, them, the $\alpha$ is the representative vector $\left(\frac{\gamma_{F}}{\sigma_{F}}, \beta\right)$

in the above formula, while $\sum$ represents the covariance matrix variance $\gamma_{F}$ and $\beta$. 
Gender

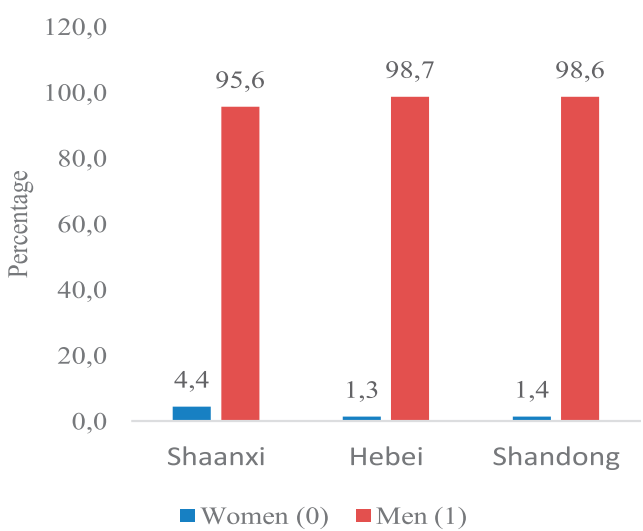

Education (years)

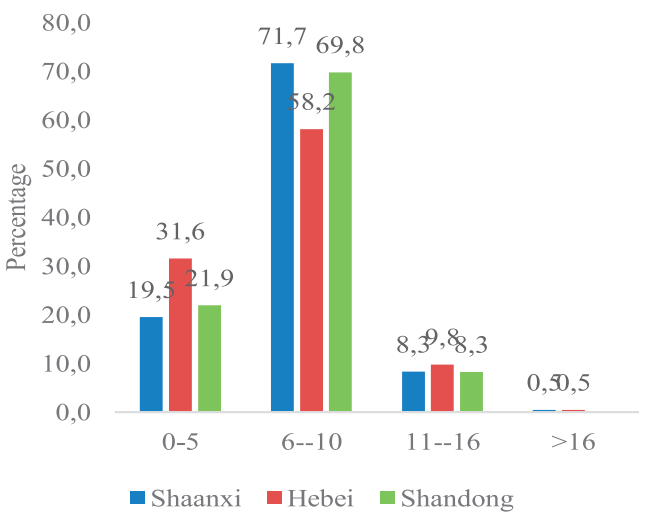

Age (Years)

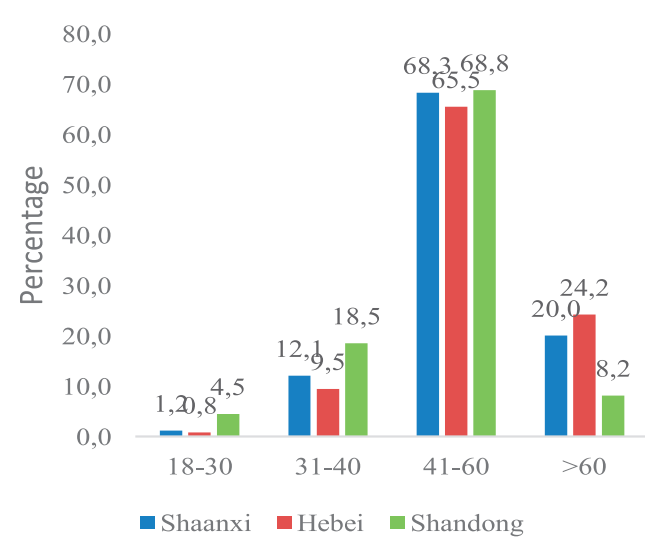

Household size

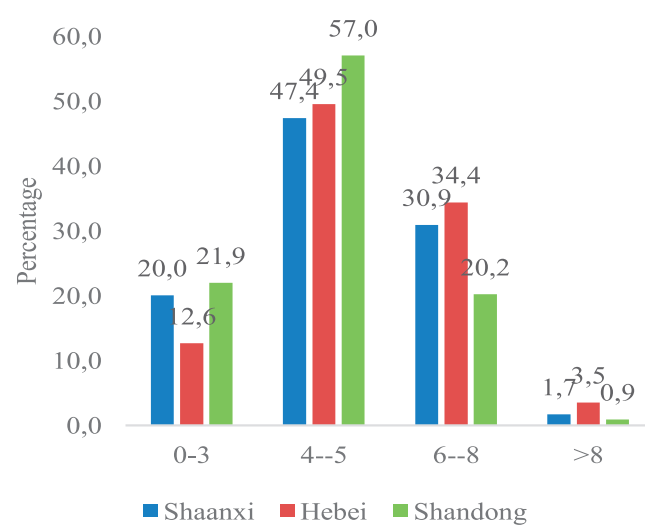

Fig. 5. Percentage share of the demographic characteristic of the households in study areas.

\section{Results and Discussions}

\section{Demographic Characteristics of the Respondents in Study Area}

The outcomes presented in Fig. 5 portray the different demographic characteristics of the sampled respondents in the study areas. Most of the sampled respondents in the study areas were Men, i.e. $95.6 \%$, $98.7 \%$ and $98.6 \%$ in Shaanxi, Hebei and Shandong provinces respectively. The data was categorized into different age groups, for instance, 18-30 years, 31-40 years, 41-60 years and more than 60 years [42]. The outcomes suggest that most of the sampled respondents in the study areas had an age between $41-60$ years, i.e. $68.3 \%$ in Shaanxi, $65.5 \%$ in Hebei and $68.8 \%$ in Shandong province respectively. While lowest share of the respondents had an average age between $18-30$ years, i.e. $1.2 \%, 0.8 \%$ and $4.5 \%$ in Shaanxi, Hebei and Shandong provinces respectively.

The outcomes of the Fig. 4, also suggest that highest percentage share of the sampled respondents had an average 6-10 years of education, for instance $71.7 \%$ in Shaanxi province, $58.2 \%$ in Hebei province and $69.8 \%$ in Shandong province, whereas, a lowest percentage share of the sampled respondents had an average years of education above 16 years. For household size, most of the sampled respondents had average family members between $4-5$, i.e. $47.4 \%, 49.5 \%$ and $57 \%$ in Shaanxi [43], Hebei and Shandong provinces respectively. While lowest number of sampled respondents had average family members greater than 8 , for instance $1.7 \%$ in Shaanxi province, $3.5 \%$ in Hebei province and $0.9 \%$ in Shandong province.

\section{The Relationship between the Degree Of Farmers' Application of Information Communication Technology and the Net Agricultural Income; Benchmark Regression}

Karlson, Holm and Breen and the ordinary least square method is used to regress the relationship between the degree of farmers' application of information communication technology and the net agricultural income. The benchmark regression results are presented in Table 2. The test result of the relationship between whether farmers used information communication technology and agricultural net income is significantly positive at the $1 \%$ level. It shows that under other conditions unchanged, the use of information communication technology in production 
Table 2. Benchmark regression results of the impact of farmers' application of information communication technology on agricultural net income.

\begin{tabular}{|c|c|c|c|c|c|}
\hline Variable & Coefficient & Standard error & Variable & Coefficient & Standard error \\
\hline ICT & $0.681^{* * *}$ & 0.053 & Cooperative & $0.178^{* *}$ & 0.090 \\
\hline GPB1 & $0.188^{*}$ & 0.132 & Distance & $-0.028^{* * *}$ & 0.003 \\
\hline GPB 2 & $0.070^{* *}$ & 0.113 & Government promotion & 0.438 & 0.352 \\
\hline Gender & 0.014 & 0.060 & Transaction cost & $-0.036^{*}$ & 0.059 \\
\hline Age & $-0.195^{* *}$ & 0.093 & Population ratio & 0.679 & 0.661 \\
\hline Education & $0.023^{* *}$ & 0.011 & Political status & $0.256^{* * *}$ & 0.177 \\
\hline Year of growing & 0.007 & 0.005 & Village cadre & $0.334^{* *}$ & 0.184 \\
\hline Planting structure & 0.629 & 0.092 & Infrastructure & $0.085^{* *}$ & 0.037 \\
\hline
\end{tabular}

Note: ICT denotes information communication technology GPB denotes green production behavior

Note: $* * *, * * *$ mean significant at the $10 \%, 5 \%$, and $1 \%$ levels respectively.

and sales will significantly increase the net income of farmers compared to farmers who do not use information communication technology. The increasing use of information communication technology by farmers can increase their net income. The possible explanation for this is that as a new production factor, investing in information communication technology will reduce transaction costs in production and sales through its own technical attributes. Through the diffusion and penetration of information communication technology in production and sales, farmers' production behavior and technology choices can also be improved. Choosing advanced production behaviors or technologies can generally bring green savings effects, and ultimately manifests itself in the application of modern production and sales. With the improvement of communication technology, the net income of farmers has increased.

The green production behavior variables all have positive impacts on the net income of farmers at a significant level of 5 and $10 \%$ level. This shows that farmers after using organic fertilizers and reduce pesticide use, although the cost increases, but the positive impact on income is greater. This is in line with the study of Crawford, Jayne [44], that the use of organic fertilizers instead of chemical fertilizers has a positive impact on improving soil fertility, improving the quality of agricultural products, and promoting sustainable agricultural development. Greenhouse technology can break the constraints of natural conditions when planting crops, improve crop production conditions, change the list and supply season of agricultural products, and create considerable economic benefits consistent with the research conclusions of [45], in addition, transaction costs and farmers' net income are negatively and significantly correlated. Birthal, Joshi [46] believe that transaction costs hinder farmers' marketing and reduce the elasticity of supply and demand [40], as well as sale prices and farmers' bargaining power [20] to reduce market surplus. That is, the increase in transaction costs will increase the cost of farmers' production and sales activities, and ultimately reduce the net income of farmers.

In terms of individual characteristics, age has a negative while education years have a positive impact on net income at a significant level of $10 \%$ respectively,

Table 3. Regression results of core variables instrumental variables.

\begin{tabular}{|c|c|c|}
\hline & (1) & (2) \\
\hline & One-stage regression & Two-stage regression \\
\hline ICT & & $\begin{array}{l}0.675^{\text {*** }} \\
(0.055)\end{array}$ \\
\hline IV (the extent of providing basic information services in the village) & $\begin{array}{c}0.193^{* * *} \\
(0.03)\end{array}$ & \\
\hline Control variable $(\mathrm{CV})$ & Control & Control \\
\hline $\mathrm{N}$ & 1189 & 1189 \\
\hline Adj-R ${ }^{2}$ & & 0.254 \\
\hline
\end{tabular}

Note: $* * *, * * *$ mean significant at the $10 \%, 5 \%$, and $1 \%$ levels, respectively. The standard errors in parentheses are the same below. ICT denotes information communication technology. 
indicating that the older the farmer the weaker the labor ability, the higher the education the farmer, higher the net income. It is necessary to strengthen the education and training of farmers [47]. It also limits its own development, and the net income is relatively small. Political outlook and if there are village cadres at home, have a positive impact on net income. Party members and government officials have a wider social network and understand more comprehensive agricultural information; therefore, more efficient production and sales will be selected in the production and sales process that will ultimately increase net income. In addition, by participating in professional cooperatives, farmers can have a fixed sales channel and obtain relatively more production and sales information through this channel, which promotes more stable and efficient production and sales behavior, and thus higher net income [48]. The negative significant surface of the distance variable is that higher the planting distance from the market, the sales difficulties are just as high, the risk is higher, the production and sales cost increase and the net income decreases. Finally, at the village level, the village market infrastructure is significantly positively correlated with net income at the 5\% level. Cornia [49] developed a farmers' income production function that included the rural information resource index, and analyzed the impact of the rural information resource index on farmers' income. They believed that every $1 \%$ increase in the input of rural information resources would lead to an increase of $0.378 \%$ in farmers' income. That is, the more complete the market infrastructure in the area where farmers are located, the more information resources they provide, and the more convenient it is for farmers to conduct production and sales activities, and therefore net income will be higher.

\section{Endogenous Problems}

Using the OLS model to estimate the above equations may have endogenous problems. First, some unobservable production and sales problems may affect both the degree of farmers' use of information communication technology and net income, and there is a problem of missing variables; the second is whether to adopt information communication technology is the self-selection of farmers as "rational people", so there is selective bias. This article first tries to use the instrumental variable method to alleviate the endogenous problem. Specifically, the degree of village agricultural information service provision is used as an instrument variable for farmers to use information communication technology. The adoption of this instrumental variable is based on the following three considerations: One is to satisfy the "relevance" condition of instrumental variables. Basic village-level agricultural information services, such as broadband access, have much to do with whether farmers use the Internet. The second is to meet the requirements of the "exogeneity" assumption of instrumental variables. Because the level of agricultural service provision at the village level has no direct effect on the net income of each individual farmer. The third is based on the availability of data. The level of agricultural information service provision at the village level was obtained during the 2017 fund project survey.

What needs to be explained is that; in the case of "exactly identification", it is difficult to statistically verify whether the exogeneity assumption of instrumental variables is satisfied. This paper draws on the ideas of [50], and returns the net income of farmers to both the degree of farmers' use of information communication technology and the tool variables. If the instrumental variable only indirectly affects the net income of the farmer using information communication technology by the farmer, then in the above regression equation, the instrumental variable should have no significant impact on the net income of the farmer while controlling the degree of the farmer's use of information communication technology. Verifying the regression results of the instrumental variable "exogeneity", the results show that the degree of villagelevel agricultural information service provision of the instrumental variable in this study is not significant, and the variable of the degree of farmers using information communication technology is significantly positive. At the same time, when net income of the farmers and the degree of farmers' use of information communication technology and the degree of villagelevel agricultural information service provision are regressed respectively, and both are significant. This shows that the instrumental variables in this study do not directly affect the net income of farmers, but only affect the net income of farmers using information communication technology.

This paper uses the two-stage least square method to estimate the model. The results are reported in Table 5. The one-stage regression results in column (1) show that the selected instrumental variables in this paper are significantly positively correlated with endogenous variables, and the assumption of correlation is fulfilled. The two-stage regression results in column (2) show that the coefficient signs of the variable of the degree of farmers using information communication technology is positive and significant at the $1 \%$ level, which is consistent with the benchmark regression result, and hence research hypothesis 1 is confirmed again. Controlling other conditions unchanged, every time a standard deviation (1.382) that a farmer uses information communication technology doubles, the net income of a farmer will significantly increase by a standard deviation of 0.517 times $^{3}$. In short, the regression results of this article mean that the integration of information and

\footnotetext{
The calculation method is $\left(\sigma_{i c t} / \sigma_{Y}\right) / \beta_{F}, \sigma_{i c t}$ and $\sigma_{Y}$ are the standard deviation of the core explanatory variable and the explained variable. (Fuchs 2008).
} 
Table 4. Robustness test results of replacing core explanatory variables.

\begin{tabular}{|c|c|c|}
\hline & $(1)$ & $(2)$ \\
\hline Whether to actively use ICT & One-stage regression & Two-stage regression \\
\hline IV & & $0.661^{* * *}(0.351)$ \\
\hline CV & $0.105^{* * *}(0.023)$ & Control \\
\hline $\mathrm{N}$ & Control & 1189 \\
\hline Adj-R & 1189 & 0.253 \\
\hline
\end{tabular}

Note: ICT denotes information communication technology and CV denotes control variables and IV denotes independent variables.

Table 5. Robustness test results of regional variables.

\begin{tabular}{|c|c|c|c|}
\hline & (1) & (2) & (3) \\
\hline Province & Hebei & Shandong & Shaanxi \\
\hline ICT & $\begin{array}{l}0.504^{* * *} \\
(0.202)\end{array}$ & $\begin{array}{l}0.630^{* * *} \\
(0.188)\end{array}$ & $\begin{array}{l}0.457^{* *} \\
(0.175)\end{array}$ \\
\hline $\mathrm{CV}$ & Control & Control & Control \\
\hline $\mathrm{N}$ & 602 & 798 & 589 \\
\hline Adj-R ${ }^{2}$ & 0.249 & 0.283 & 0.251 \\
\hline
\end{tabular}

Note: ICT denotes information communication technology and CV denotes control variables

agricultural modernization into agricultural activities will have a certain income-increasing effect, which will help the development of agricultural information to realize the improvement of farmers' income.

\section{Robustness Test}

\section{Replace the Core Explanatory Variables}

Mtega and Msungu [17] studied that the value of information services can only be realized when they are accessed, understood, and used in a timely manner. The most important thing is how to use information communication technology, not own them [33]. In the questionnaire of "Does the farmer take the initiative to use information communication technology to obtain agricultural related information", if the farmer answered "yes" to the question, the value is 1 ; otherwise, the value is 0 . Take it as a core explanatory variable, and then regress the model. The results are reported in Table 4, the results showed that the coefficient of whether farmers actively use information communication technology to obtain agricultural information is significantly positive. The benchmark regression results in Table 1 are again confirmed. This also shows that farmers who actively use information communication technology to obtain relevant agricultural information in production and sales will play a role in different links of production and sales, and ultimately realize their net benefits. This is consistent with the research results of Xiang, Wei-Ping [51] that found that farmers who inquired about agricultural information through various channels had $45.8 \%$ higher agricultural operating income than those who did not.

\section{Consider the Impact of Regional Differences}

Although the three provinces of Hebei, Shandong, and Shaanxi are the main provinces for vegetable cultivation and sales, the three provinces are located in different locations. They are located in the Northwest and North China regions, and there are also certain differences in the level of agricultural economic development. Therefore, there must be certain differences in the patterns of planting and selling vegetables. In different provinces, there should be differences in the degree and net income of farmers using information communication technology. In this end, this article conducts the following regional differences analysis. The results in Table 5 show that the positive effect of the use of information communication technology on the net income of farmers still hold in different regions. At the same time, it can be seen that there are certain differences in the application of information communication technology by farmers in the process of agricultural production and sales in these three provinces and the possible influencing factors are also research directions that can be consider in the future. 
Table 6. The direct and indirect effects of the application of information communication technology on the net income of farmers.

\begin{tabular}{|c|c|c|c|c|}
\hline & Coefficient & Standard error & Z value & $\mathrm{P}>|\mathrm{Z}|$ \\
\hline Total effect & $0.733^{* * *}$ & 0.024 & 30.35 & 0.000 \\
\hline Direct effect & $0.632^{* * *}$ & 0.242 & 30.02 & 0.000 \\
\hline Indirect effect & $0.101^{*}$ & 0.102 & 1.37 & 0.079 \\
\hline
\end{tabular}

Table 7. Decomposition of the indirect effects of the application of information communication technology on the net income of farmers.

\begin{tabular}{|c|c|c|c|c|}
\hline Variable & Coefficient & Standard Error & Proportion of Indirect Effect & Proportion of Total Effect \\
\hline GPB1 & 0.16 & 0.14 & 56.30 & 7.7 \\
\hline GPB2 & 0.08 & 0.06 & 15.42 & 3.6 \\
\hline
\end{tabular}

Note: GPB denotes green production behavior

Analysis of the Mechanism of the Use of Information Communication Technology Affecting Farmers' Net Income

The increased use of information communication technology can produce income-increasing effects. Can the use of information communication technology lead to changes in green production behavior by reducing transaction costs and achieve the goal of increasing farmers' income? This article tested the above-mentioned intermediary influence mechanism by constructing the Karlson, Holm and Breen model, and measure the indirect effect of two specific intermediary variables of green production behavior on farmers' adoption of technology.

From the data in the table, we can see that the total effect of the application of information communication technology on the net income of farmers is 0.733 , which is significant at the $1 \%$ significance level (judged by the $\mathrm{z}$ test). The direct utility is 0.632 and the indirect effect is 0.101 . The direct effect and the indirect effect are significant and positive at $1 \%$ and $10 \%$ level of significance, which is consistent with the previous test results. The application of information communication technology has a greater direct effect on the net income of farmers, accounting for $86.2 \%$ of the total effect. The indirect effect only produced about $13.8 \%$ of the overall effect. In order to explore the degree of influence of different intermediary variables, this study only split the introduction effect in one-step. From the perspective of the composition of indirect effects (Table 7), the application of information communication technology has different indirect effects on the net income of farmers through the two variables of green production behavior. The indirect effect coefficients are 0.16 and 0.08 , respectively.

The application level of information communication technology has the greatest indirect impact on the net income of farmers using organic fertilizer variables in green production behavior, accounting for $56.30 \%$ of the indirect effect and $7.7 \%$ of the total effect.
The increase in its net income played a major role. The reduction of pesticide use accounts for $15.42 \%$ of the indirect effects. Information communication technology has the function of green technology to a certain extent [52]. With the development of safe production and green agriculture, farmers can use information technology to enhance environmental protection awareness as well as understand the safety production behaviors. The individual benefits and social benefits that come will ultimately promote the adoption of farmers.

As a production factor, information communication technology can play a role in technological advancement when it is brought into the production process, and can also be complementary with other production technologies, drive the overall production technology progress, and thus achieve the goal of improving efficiency [53]. On the one hand, information communication technology reduces the cost of information search to encourage farmers to have a more comprehensive understanding of green production methods. The more symmetrical agricultural production information will reduce various uncertainties in the process of changing production behaviors, thereby alleviating risk aversion for farmers and prevent choosing production behavior and technology [51]. On the other hand, information communication technology can promote changes in the use of factors in production activities in the short-term and reduce the cost of supervision and execution after purchase by increasing farmers' bargaining power when purchasing organic fertilizers [54]. Therefore reducing the cost of production factors, to encourage farmers to be more willing to choose environment friendly organic fertilizers and to reduce the use of pesticides and other green production behaviors [55]. When information communication technology is embedded in the production process of farmers, in addition to improving the level of production sustainability, farmers' income will also increase, which can be confirmed in domestic and foreign research. Pretty, 
Hine [7] used 15 cases surveyed in Africa to conduct a comparative study and found 12 cases showing that green organic agricultural production is beneficial to the income growth of producers. Kilcher [56] concluded that, "green organic agricultural production methods will be beneficial to farmers' income growth". With the deepening of the integration of information communication technology and farmers' production, not only relying on the technological advancement of information communication technology itself to increase farmers' income, but also by causing farmers to choose more efficient and green technologies and behaviors to increase farmers' income and long-term benefits. At present, in the context of the upgrading of the consumption structure of Chinese residents, the problem of structural imbalance in the supply and demand of some agricultural products has become increasingly prominent. The development of highquality, diversified, and specialized agricultural products is relatively lagging, and it is urgent to promote green development and sustainable use of resources. With the development and progress of science and technology, China's agriculture is developing in the direction of informatization, technology, safety, ecology, and sustainability. These new trends require agriculture to pay more attention to efficiency and environmental protection based on applied technology. The article meets the requirements of China's future agricultural development and discusses how to promote agriculture through new technologies.

\section{Conclusion, Recommendations and Limitations}

Based on the 2017 micro survey data of vegetable growers in China, this study uses ordinary least squares method, instrumental variable method and Karlson, Holm and Breen model to empirically test the "green" effect of vegetable growers' use of information communication technology on their net income. The results of the study found that under other conditions unchanged, increasing farmers' use of information communication technology significantly increased their net income. The robustness test showed that the regression results of this study do not change with the change of variable measurement methods, nor do they vary with the regional attributes of the sampled farmers. The changes in green production behavior caused by the application of information communication technology by farmers have indirect effects using organic fertilizers and the reduction of pesticide use, and the indirect effects account for $13.8 \%$ of the total effects.

In summary, the main findings of the current research work are: in the process of agricultural production, farmers use information and communication technology not only to directly increase their net income, but also to indirectly increase the net income of farmers by changing their production behavior: increasing the use of organic fertilizers and reducing the use of pesticides. That is, the use of information communication tools makes agriculture more informatized, green, and efficient.

The research conclusions provide the following four points of enlightenment.

First, the use of information communication technology in production and sales of farmers can promote good changes in their market behavior and bring "information dividends" to farmers. Therefore, farmers should take the government's information demonstration and promotion projects as an opportunity to increase information supply by using information communication technology in production and sales, use green technology, reduce environmental pollution, and increase net income. Second, in support of government policy, government at all levels should increase support for agricultural information through methods such as subsidies for communication equipment and preferential information technology in rural areas. As well as promote modern and green agricultural technology and production materials through information technology. Reduction in corresponding expenses to encourage farmers to use information communication technology and to understand relevant information to change traditional production and sales methods. Increase the use of organic fertilizers, and to promote farmers to adopt green ecological agriculture model changes and finally embarks on the road of sustainable agricultural development. The third is to establish and improve the market information system for agricultural products and increase the supply of market environmental information. The public goods characteristics of agricultural product information can easily lead to the "free rider" phenomenon, but the collection of information requires a certain cost, which leads to insufficient supply of market information. The government should pay attention to the collection, integration and release of the relevant agricultural product information, establishing a village-level information-sharing platform, and encourage operators and other profitable enterprises, public welfare institutions and government extension organizations to use public information resources to provide information development, services and free promotion of agricultural and rural areas. For improvement the coverage of information services, a need to establish a modern agricultural product market information service system, and weaken the degree of information asymmetry in the agricultural product market. The fourth is to increase government promotion and training while improving the education level of farmers, so that farmers can learn how to use technology more than their potential, strengthen the ability to use of information tools in rural areas and training on the importance and usefulness of agricultural market information. Moreover, improving farmers' awareness and level of active use of information communication technology, and let those who own mobile phones and computers, 
while farmers can actively and effectively use technology, they can learn more about environmental pollution hazards, making the agricultural sound field greener and more sustainable.

The limitations of the current study include, on the one hand, the current research targets only include farmers in the main vegetable growing areas in China, and fail to reflect the overall situation; on the other hand, green production technology includes many aspects, and the article currently only uses two variables to characterize it, which is not comprehensive enough. This is the direction for the next preparation to continue research.

\section{Acknowledgement}

This research was funded through the National Natural Science Foundation of China "Influence Mechanism of Information and Communication Technology Application on Farmers' Market Participation and Performance - Based on the Perspective of Transaction Costs," dossier number 71773093.

\section{Conflict of Interest}

The authors declare no conflict of interest

\section{References}

1. TAKESHIMA H., LIVERPOOL-TASIE L.S.O. Fertilizer subsidies, political influence and local food prices in sub-Saharan Africa: Evidence from Nigeria. Food Policy 54, 11, 2015.

2. TAKESHIMA H., ADHIKARI R.P., SHIVAKOTI S., KAPHLE B.D., KUMAR A. Heterogeneous returns to chemical fertilizer at the intensive margins: Insights from Nepal. Food Policy 69, 97, 2017.

3. ZHU X.-K., GUO W.-S., ZHOU J.-L., HU H., ZHANG Y., LI C.-Y., FENG C.-N., PENG Y.-X. Effects of nitrogen on grain yield, Nutritional and Processing Quality of Wheat for Different End Uses. Agricultural Sciences in China 2 (6), 609, 2003.

4. YAN Y., TIAN J., FAN M., ZHANG F., LI X., CHRISTIE P., CHEN H., LEE J., KUZYAKOV Y., SIX J. Soil organic carbon and total nitrogen in intensively managed arable soils. Agriculture, Ecosystems \& Environment 150, 102, 2012.

5. GU B., JU X., CHANG J., GE Y., VITOUSEK P. M. Integrated reactive nitrogen budgets and future trends in China. Proceedings of the National Academy of Sciences 112 (28), 8792, 2015.

6. HONG C., LIU M., LI W. Evaluation on the policies of non-point pollution control of chemical fertilizer in China. J Arid Land Resour. Environ. 29, 1, 2015.

7. PRETTY J., HINE R., TWAROG S. In Organic agriculture and food security in Africa, UNEP-UNCTAD Capacity-Building Task Force on Trade. New York and Geneva: United Nations Conference on Trade and
Development/United Nations Environment Programme, 2008.

8. CHEN X., CUI Z., FAN M., VITOUSEK P., ZHAO M., MA W., WANG Z., ZHANG W., YAN X., YANG J. Producing more grain with lower environmental costs. Nature 514 (7523), 486, 2014.

9. CUI Z., ZHANG H., CHEN X., ZHANG C., MA W., HUANG C., ZHANG W., MI G., MIAO Y., LI X. Pursuing sustainable productivity with millions of smallholder farmers. Nature 555 (7696), 363, 2018.

10. ZHANG J., MANSKE G., ZHOU P.Q., TISCHBEIN B., BECKER M., LI Z.H. Factors influencing farmers' decisions on nitrogen fertilizer application in the Liangzihu Lake basin, Central China. Environment, Development and Sustainability 19 (3), 791, 2017.

11. FOSTER A.D., ROSENZWEIG M.R. Microeconomics of technology adoption. Annu. Rev. Econ. 2 (1), 395, 2010.

12. FEDER G. Pesticides, information, and pest management under uncertainty. American Journal of Agricultural Economics 61 (1), 97, 1979.

13. STIGLER G.J. The economics of information. Journal of political economy 69 (3), 213, 1961.

14. BROWN J.R., GOOLSBEE A. Does the Internet make markets more competitive? Evidence from the life insurance industry. Journal of political economy 110 (3), 481, 2002.

15. AKER J.C. Does digital divide or provide? The impact of cell phones on grain markets in Niger. Center for Global Development working paper (154), 2008.

16. DILLON B., KAMANZI A., AKER J., BLUMENSTOCK J. Communication, search, and mobile phones: A telephone directory intervention in Tanzania. Research proposal for BASIS/AMA 2015.

17. MTEGA W.P., MSUNGU A.C. Using information and communication technologies for enhancing the accessibility of agricultural information for improved agricultural production in Tanzania. The Electronic Journal of Information Systems in Developing Countries 56 (1), 1, 2013.

18. DEICHMANN U., GOYAL A., MISHRA D. Will digital technologies transform agriculture in developing countries? The World Bank: 2016.

19. HILTY L.M., AEBISCHER B. ICT for sustainability: An emerging research field. In ICT innovations for Sustainability, Springer 3, 2015.

20. WEI W.U., LIU R., YEYONG M.O. CATAS, Information Quality,Transaction Costs and Farmers' Sale Prices Evidence from 466 rubber farmers in Hainan and Yunnan provinces. Issues of Forestry Economics 2015.

21. SVENSSON J., YANAGIZAWA D. Getting prices right: the impact of the market information service in Uganda. Journal of the European Economic Association 7 (2-3), 435, 2009.

22. JENSEN R. The digital provide: Information (technology), market performance, and welfare in the South Indian fisheries sector. The quarterly journal of economics $\mathbf{1 2 2}$ (3), 879, 2007.

23. NAKASONE E., TORERO M. A text message away: ICTs as a tool to improve food security. Agricultural Economics 47 (S1), 49, 2016.

24. GOYAL A. Information, direct access to farmers, and rural market performance in central India. American Economic Journal: Applied Economics 2 (3), 22, 2010.

25. NAKASONE E., TORERO M., MINTEN B. The power of information: The ICT revolution in agricultural development. Annu. Rev. Resour. Econ. 6 (1), 533, 2014. 
26. CAMACHO A., CONOVER E. The impact of receiving price and climate information in the agricultural sector. Documento CEDE (2010-40), 2010.

27. MITRA S., MOOKHERJEE D., TORERO M., VISARIA S. Asymmetric information and middleman margins: An experiment with west bengal potato farmers. The Bureau for Research and Economic Analysis of Development (BREAD) Working Paper (401), 2013.

28. FAFCHAMPS M., MINTEN B. Impact of SMS-based agricultural information on Indian farmers. The World Bank Economic Review 26 (3), 383, 2012.

29. AKER J.C., KSOLL C. Can mobile phones improve agricultural outcomes? Evidence from a randomized experiment in Niger. Food Policy 60, 44, 2016.

30. ZHANG W., JI H., KOLBE H., XU A. Estimation of agricultural non-point source pollution in China and the alleviating strategies II. Status of agricultural non-point source pollution and the alleviating strategies in European and American countries. Scientia agricultura sinica 37 (7), 1018, 2004.

31. WU Y., XI X., TANG X., LUO D., GU B., LAM S. K., VITOUSEK P.M., CHEN D. Policy distortions, farm size, and the overuse of agricultural chemicals in China. Proceedings of the National Academy of Sciences $\mathbf{1 1 5}$ (27), 7010, 2018.

32. SHENG J., LU Q. The influence of information communication technology on farmers' sales channels in environmentally affected areas of China. Environmental Science and Pollution Research 1, 2020.

33. ZANELLO G. Mobile phones and radios: Effects on transactions costs and market participation for households in Northern Ghana. Journal of Agricultural Economics $\mathbf{6 3}$ (3), 694, 2012.

34. BANDIERA O., RASUL I. Social networks and technology adoption in northern Mozambique. The economic journal 116 (514), 869, 2006.

35. ZHANG L., ZHOU L. The Study of the Impact of Integration of Informationization and Industrialization on Corporate Innovation:From the Perspective of Enterprise Value Chains. Journal of Finance \& Economics 7, 10, 2016.

36. BRUNELLE T., DUMAS P., SOUTY F., DORIN B., NADAUD F. Evaluating the impact of rising fertilizer prices on crop yields. Agricultural economics 46 (5), 653, 2015.

37. ISMAIL I.J., SRINIVAS M., TUNDUI H. Transaction costs and market participation decisions of maize smallholder farmers in dodoma region, Tanzania. Global Journal of Biology, Agriculture and Health Sciences 4 (2), 12,2015

38. JU X., GU B., WU Y., GALLOWAY J.N. Reducing China's fertilizer use by increasing farm size. Global environmental change 41, 26, 2016.

39. LATRUFFE L., PIET L. Does land fragmentation affect farm performance? A case study from Brittany, France. Agricultural systems 129, 68, 2014.

40. MINOT N. Effect of transaction costs on supply response and marketed surplus: Simulations using non-separable household models. Markets and Structural Studies Division Discussion Paper 36, 1999.
41. KARLSON K.B., HOLM A., BREEN R. Total, direct, and indirect effects in logit models. 2010.

42. KHAN S.U., LIU G., ZHAO M., CHIEN H., LU Q., KHAN A.A., ALI M.A.S., MISBAHULLAH. Spatial prioritization of willingness to pay for ecosystem services. A novel notion of distance from origin's impression. Environmental ence and Pollution Research 27 (3), 3100, 2020.

43. KHAN S. U., HAYAT S., LIU G., ZHAO M., XIA X. Improvisation of indigenous Environmental benefit transfer and valuation for cleaner environment: Choice experiment across Northwest China. Journal of Cleaner Production 2020.

44. CRAWFORD E.W., JAYNE T.S., KELLY V.A. Alternative approaches for promoting fertilizer use in Africa, with particular reference to the role of fertilizer subsidies. 2005.

45. DUXBURY J.M. The significance of agricultural sources of greenhouse gases. Fertilizer research 38 (2), 151, 1994.

46. BIRTHAL P.S., JOSHI P.K., GULATI A. Vertical coordination in high-value commodities: Implications for smallholders 2005 .

47. HUANG J., HUANG Z., JIA X., HU R., XIANG C. Long-term reduction of nitrogen fertilizer use through knowledge training in rice production in China. Agricultural Systems 135, 105, 2015.

48. HOU J., HUO X., YIN R. Does computer usage change farmers' production and consumption? Evidence from China. China Agricultural Economic Review 2019.

49. CORNIA G. A. Farm size, land yields and the agricultural production function: An analysis for fifteen developing countries. World development 13 (4), 513, 1985.

50. FANG Y., ZHAO Y. Looking for Instruments for Institutions: Estimating the Impact of Property Rights Protection on Chinese Economic Performance. Economic Research Journal 2011.

51. XIANG L.I., WEI-PING X.U., GUO Y.T., RAO X.Y., YAN D.H., ZHANG H., HAN W.T. Impact of information technology application on farmers' income. Journal of Agricultural Ence \& Technology 2014.

52. MAY G., STAHL B., TAISCH M., KIRITSIS D. Energy management in manufacturing: From literature review to a conceptual framework. Journal of cleaner production 167, 1464, 2017.

53. FUCHS C. The implications of new information and communication technologies for sustainability. Environment, Development and Sustainability 10 (3), 291, 2008.

54. BEUERMANN D.W. Information and Communications Technology, Agricultural Profitability and Child Labor in Rural P eru. Review of Development Economics 19 (4), 988, 2015

55. CROPPENSTEDT A., DEMEKE M. Determinants of adoption and levels of demand for fertiliser for cereal growing farmers in Ethiopia. University of Oxford, Institute of Economics and Statistics, Centre for the ...: 1996.

56. KILCHER L. How organic agriculture contributes to sustainable development. Journal of Agricultural Research in the Tropics and Subtropics, Supplement 89, 31, 2007. 